\title{
Planowanie i dokonywanie wydatków publicznych $w$ ramach budżetu obywatelskiego - uwagi de lege lata
}

Złożony do redakcji: 23.03.2020. Zaakceptowany do druku: 28.04.2020

\section{Streszczenie}

Po sześcioletnim okresie praktykowania przez polskie samorządy instrumentu budżetu obywatelskiego wyłącznie $w$ ramach lokalnie regulowanych procedur konsultacyjnych w 2018 r. po raz pierwszy weszły w życie ustawowe podstawy powyższego instrumentu partycypacji społecznej. Uchwalenie ustawowych przepisów dotyczących budżetu obywatelskiego z jednej strony niejako zalegalizowało stosowaną dotychczas praktykę samorządową, lecz z drugiej strony jednoczesne wprowadzenie obligatoryjności tego budżetu w miastach na prawach powiatu zniekształciło ideę partycypacji. W artykule przeprowadzono ocenę stosowania nowych podstaw ustawowych budżetu obywatelskiego w świetle przepisów regulujących planowanie i dokonywanie wydatków publicznych, poprzedzając ją uwagami dotyczącymi genezy wprowadzania tego instrumentu w innych krajach. Głównym celem artykułu jest dokonanie powyższej oceny przy zachowaniu równowagi argumentów za i przeciw stosowaniu budżetu obywatelskiego przez polskie samorządy. Rozważaniom zawartym w artykule towarzyszyło rzadko podejmowane w literaturze pytanie: jaki jest charakter prawny wydatków publicznych dokonywanych $\mathrm{w}$ ramach budżetu obywatelskiego?

Słowa kluczowe: budżet obywatelski, obligatoryjność budżetu obywatelskiego, wydatki na zadania budżetu obywatelskiego, zasada superficies solo cedit.

1 Dr hab. Anna Ostrowska - Państwowa Wyższa Szkoła Informatyki i Przedsiębiorczości w Łomży, Polska; e-mail: aostrowska@pwsip.edu.pl; ORCID: 0000-0001-8380-9005. Badania nie są finansowane przez żadną instytucję. 


\title{
ANNA OSTROWSKA
}

\section{Planning and Spending Public Expenditure within the Framework of Participatory Budgeting - de lege lata Remarks}

\begin{abstract}
After six years of Polish local government authorities practising participatory budgeting only within the framework of locally regulated consultation procedures, the year 2018 marked the official establishment of the statutory basis of the instrument in question. The adoption of statutory regulations for participatory budgeting has, on the one hand, legitimised the current practices of local government authorities to some extent, but on the other hand, making participatory budgets an obligatory instrument in towns and cities with poviat rights has warped the idea of participation. The article offers an assessment of the application of the new statutory basis of participatory budgeting in the light of the provisions regulating the planning and spending of public expenditure, accompanied by remarks on the origin of adoption of this instrument in other countries. The main aim of the article is to make the said assessment while maintaining a balance between the arguments for and against the utility of participatory budgeting from the perspective of Polish local government authorities. The discussion featured in the article comes with a question raised thus far quite rarely in the relevant literature: what is the legal nature of public expenditure spent within the framework of a participatory budget?
\end{abstract}

Keywords: participatory budget, obligatory participatory budgeting, expenditure on participatory budget measures, the superficies solo cedit principle. 


\section{Geneza wprowadzenia budżetu obywatelskiego w Polsce}

Analizę przepisów prawa w zakresie planowania i dokonywania wydatków publicznych w ramach budżetu obywatelskiego należałoby poprzedzić krótką refleksją nad genezą wprowadzenia powyższego instrumentu partycypacji społecznej do polskiego systemu prawnego. Obserwacja procesu decentralizacji zadań i finansów publicznych przeprowadzanego w Polsce począwszy od transformacji ustrojowej w 1989 r. skłania do sformułowania spostrzeżenia, iż kolejne instrumenty partycypacji społecznej (począwszy od uchwalenia ustawy o działalności pożytku publicznego, poprzez uchwalenie ustawy o funduszu sołeckim, a skończywszy na ustawowej regulacji budżetu obywatelskiego) służyły bardziej uzupełnianiu działalności organów jednostek samorządu terytorialnego (dalej: j.s.t.) niż realnej partycypacji społecznej i wdrażaniu idei subsydiarności. Należałoby bowiem zadać pytanie, dlaczego do tej pory nie przeprowadzono reformy dochodów j.s.t. (utrzymując system dochodów oparty na ustawie z 2003 r.) czy też nie przyjęto kompleksowej regulacji samorządowego prawa urzędniczego, lecz niejako $\mathrm{w}$ to miejsce proponowano kolejne instrumenty partycypacji społecznej. Z pewnością bowiem żadnego z tych instrumentów (nawet funduszu soleckiego) nie można uznać za tzw. trzecią reformę samorządową, która by ten samorząd terytorialny wzmocniła finansowo i dookreśliła kompetencyjnie.

Praktyka polskich j.s.t. w tworzeniu budżetów obywatelskich zapoczątkowana w 2012 r. nie wywołała kontrowersji zarówno wśród przedstawicieli nauki prawa finansowego, jak i organów orzeczniczych, co wynikało, być może, z wielkiej roli samorządów terytorialnych, jaką odgrywały w rozwoju kraju zarówno w wymiarze społecznym, jak i infrastrukturalnym. Należało jednak wówczas zadać pytanie, dlaczego tradycyjną formę partycypacji pośredniej (demokracji przedstawicielskiej) w postaci wybieralnych organów j.s.t., a także przyjmowany przez te organy budżet j.s.t. zaczęto uzupełniać o formy bezpośrednie? Dlaczego uchwalany przez radę budżet gminy/powiatu, sam w sobie co do istoty będący przecież budżetem obywatelskim, zaczął być modyfikowany (udoskonalany) przez wprowadzenie budżetów (funduszy) partycypacji bezpośredniej?

Znamienne są przesłanki wprowadzania budżetu partycypacyjnego (dalej: $\mathrm{BO})^{2} \mathrm{w}$ innych krajach, wśród których należy wymienić: chęć odzyskania zaufania

2 Budżet obywatelski (civic budget) synonimicznie traktowany jest $\mathrm{z}$ budżetem partycypacyjnym (participatory budget). 
mieszkańców, chęć poprawy warunków życia mieszkańców czy wyrównywanie nierówności społecznych. Takie właśnie przesłanki przyświecały wprowadzaniu pierwszego na świecie budżetu partycypacyjnego $\mathrm{w}$ brazylijskim mieście Porto Alegre w 1989 r. Na uwagę zasługuje w szczególności przesłanka w postaci „uzyskania zaufania mieszkańców”, gdyż może ona świadczyć raczej o politycznych podstawach instrumentów partycypacji społecznej niż o realnych zamiarach usprawnienia systemu realizacji usług publicznych świadczonych mieszkańcom ${ }^{3}$. Jak wskazuje Urszula K. Zawadzka-Pąk, we włoskim mieście Pieve Emmanuele (należącym do metropolii Mediolanu) budżet partycypacyjny „został wprowadzony w 2003 r., gdy wybory wygrała nowa centrolewicowa partia, która chciała odzyskać zaufanie mieszkańców do organów władz lokalnych miasta. Nowy burmistrz musiał zmierzyć się z głębokim kryzysem zaufania społecznego i do jego odbudowy chciał wykorzystać właśnie budżet partycypacyjny"4.

Charakterystyczne są także obawy poszczególnych państw przed wprowadzaniem ustawowych podstaw BO. We Włoszech nie przyjęto regulacji ustawowej budżetu partycypacyjnego, gdyż zdaniem polityków powodowałoby to usztywnienie i zbiurokratyzowanie tego instrumentu, a poza tym wiązałoby się z formalnym przekazaniem części uprawnień obywatelom. Podobnie w Belgii ze względu na specyficzną narodowościową sytuację, zagrażającą niekiedy nierozerwalności państwa, budżet partycypacyjny, tak jak i referendum, mają charakter niewiążących konsultacji. Ponadto znamienny jest również fakt, iż w niektórych krajach budżet obywatelski nie powstawał z oddolnej inicjatywy obywateli lub samych samorządów lokalnych, lecz z inicjatywy odgórnej: związków zawodowych (np. w Argentynie), partii politycznych (np. w Brazylii), ruchu społecznego przekształconego w koalicję wyborczą (np. Włochy) czy nawet Banku Światowego (np. w Kenii i Indonezji) ${ }^{5}$.

Niewątpliwie instrumenty partycypacji społecznej, takie jak budżet obywatelski czy fundusz sołecki, posiadają swoje pozytywne cechy, wśród których wymienić można nie tylko aktywizację lokalnych społeczności, ale przede wszystkim konieczność nawiązywania dialogu urzędników z mieszkańcami. Podobnie jednak jak koncepcje nowego zarządzania w administracji (takie jak New Public Management lub Local Governance) po latach praktykowania okazywały się być nieefektywne ${ }^{6}$, tak w odniesieniu do omawianej formy partycypacji społecznej zauważa się jej

Podobnie: C. Kowanda, Bierzcie i dzielcie, „Polityka” 2014, 14, s. 46.

4 U.K. Zawadzka-Pąk, Ochrona dobra wspólnego poprzez budżet partycypacyjny (obywatelski). Studium aksjologiczno-prawne, Białystok 2019, s. 139.

5 Ibidem, s. 130-163.

6 Zob. G. Stoker, Transforming Local Governance: from Thatcherism to New Labour, London 2004, s. 154-156. Podobnie: L. Rajca, Reformy samorządu terytorialnego w Anglii w latach 1997-2010, Toruń 2012, s. 272-282. 
wady 7 . Wśród wad budżetu obywatelskiego wymienia się m.in.: brak zainteresowania mieszkańców, nadmierną koncentrację na realizacji drobnych projektów infrastrukturalnych, zgłaszanie projektów w ramach BO wywołujących sprzeciw wśród lokalnej społeczności, brak zaufania do samego procesu weryfikacji zgłaszanych projektów oraz głosowania nad nimi, a także przypadki wykonania przez gminę projektu niezgodnie z jego zgłoszoną wersją ${ }^{8}$. Ponadto wskazuje się, że instrumenty te nie nadają się do finansowania inwestycji wieloletnich ${ }^{9}$, co zostanie zweryfikowane w dalszej części artykułu.

\section{Kwalifikowane wejście w życie przepisów ustawowych}

Wprowadzenie ustawowych podstaw funkcjonowania budżetu obywatelskiego w Polsce należy ocenić pozytywnie z punktu widzenia konstytucyjnej zasady legalizmu (art. 7 Konstytucji RP). Dotychczas bowiem organy władzy samorządowej, praktykując budżet obywatelski ${ }^{10}$, poczynając od pierwszego takiego budżetu wprowadzonego w Sopocie w 2012 r., działały wyłącznie na podstawie ogólnego przepisu o konsultacjach społecznych. Przyjmując zgodnie z zaleceniami doktryny, iż praktycznie wydatkowanie jakiejkolwiek kwoty pieniężnej pochodzącej z dochodów gminnych można uznać za "sprawę ważną"11, samorządy gminne (głównie gmin miejskich oraz wszystkich miast na prawach powiatu) praktykowały BO na podstawie art. 5a ust. 1-2 u.s.g. ${ }^{12}$ oraz ogólnego zadania własnego gminy określonego

7 O niepowodzeniach koncepcji demokracji partycypacyjnej w Wielkiej Brytanii zob.: L. Rajca, Local governance a partycypacja obywateli, [w:] J. Wojnicki (red.), Europejskie modele samorzadu terytorialnego. Stan obecny i perspektywy, Warszawa 2014, s. 123-145.

8 Por.: Ewaluacja procesu wdrażania budżetu obywatelskiego w Krakowie w 2016 r. Raport końcowy, Załącznik 4, Miejskie Centrum Dialogu, Kraków 2016, s. 24-31, https://www.bip.krakow.pl/?dok_id=73898 (dostęp: 15.10.2020).

$9 \quad$ K. Czarnecki, Udział mieszkańców w ustalaniu wydatków budżetu gminy w ramach tzw. budżetu partycypacyjnego (na przykładzie Torunia w latach 2013-2014), "Prawo Budżetowe Państwa i Samorządu” 2014, 2, s. 129.

10 W 2018 r. na 314 powiatów BO praktykowało 5 powiatów, zaś na 16 samorządów województw - praktykowało go 8. Instrument ten w ogóle nie był wykorzystywany w gminach wiejskich (z racji możliwości wyodrębniania tam funduszy sołeckich). W największym wymiarze zaś praktykowany był w gminach miejskich (na $302-207$ posiadało BO), a także przez wszystkie miasta na prawach powiatu (66). Na podstawie: U.K. Zawadzka-Pąk, op. cit., s. 103.

11 Zob.: D.J. Kościuk, J.E. Kulikowska-Kulesza, U.K. Zawadzka-Pąk, E. Lotko, Budżet partycypacyjny jako instrument wspierania realizacji lokalnych zadań publicznych - analiza administracyjno-finansowa miast wojewódzkich, [w:] B. Dolnicki (red.), Sposoby realizacji zadań publicznych, Warszawa 2017, s. 353-354.

12 Ustawa z 8.03.1990 r. o samorządzie gminnym (t.j. Dz.U. z 2019 r., poz. 506 z późn. zm.), dalej: u.s.g. Podobne przepisy o konsultacjach społecznych znajdują się w art. 3d ust. 1-2 ustawy 
w art. 7 ust. 1 pkt 17 u.s.g. - „wspierania i upowszechniania idei samorządowej, w tym tworzenia warunków do działania i rozwoju jednostek pomocniczych i wdrażania programów pobudzania aktywności obywatelskiej".

Z dniem 31.01.2018 r. na wszystkich stopniach samorządu terytorialnego budżet obywatelski uzyskał bezpośrednie podstawy ustawowe, przy czym art. 15 ustawy nowelizującej ${ }^{13}$ stanowi, iż nowe regulacje ustawowe "stosuje się do kadencji organów jednostek samorządu terytorialnego następujących po kadencji, w czasie której niniejsza ustawa weszła w życie". Brzmienie powyższego przepisu temporalnego, jakkolwiek dość rzadko stosowane przez ustawodawcę ${ }^{14}$, wydaje się jasno wskazywać, iż wszystkie nowe ustawowe przepisy dotyczące BO (art. 5a ust. 3-7 u.s.g., art. 3 d ust. 3-6 u.s.p. i art. 10a ust. 3-6 u.s.w.) adresowane są do kolejnych kadencji organów j.s.t. następujących po kadencji 2014-2018.

Należy jednak podkreślić, iż z dniem wejścia w życie nowych przepisów ustawowych rozpoczął się niejako okres zawieszenia w podejmowaniu działań, które byłyby sprzeczne z tymi przepisami, aż do momentu „uprawomocnienia się" podstawy działania nowych organów ${ }^{15}$. W sytuacji zastosowania przez ustawodawcę kwalifikowanego wejścia w życie nowych przepisów podmioty stosujące prawo nie mogą nowych obowiązujących już przepisów „nie zauważać”, co oznacza, że nie powinny podejmować działań sprzecznych z owymi nowymi przepisami.

\section{Obligatoryjny charakter budżetu obywatelskiego w miastach na prawach powiatu}

Historia budżetów obywatelskich w innych krajach dowodzi, iż nadawanie instrumentom partycypacji społecznej charakteru obligatoryjnego nie prowadzi do

z 5.06.1998 r. o samorządzie powiatowym (Dz.U. z 2018 r., poz. 995 z późn. zm.), dalej: u.s.p. oraz w art. 10a ust. 1-2 ustawy z 5.06.1998 r. o samorządzie województwa (Dz.U. z 2018 r., poz. 913 z późn. zm.), dalej: u.s.w.

13 Ustawa z 11.01.2018 r. o zmianie niektórych ustaw w celu zwiększenia udziału obywateli w procesie wybierania, funkcjonowania i kontrolowania niektórych organów publicznych (Dz.U. poz. 130 z późn. zm.), dalej: ustawa nowelizująca.

14 Przykładem analogicznego przepisu temporalnego jest przepis art. 2 ustawy z dnia 7.05.2009 r. o zmianie Konstytucji Rzeczpospolitej Polskiej (Dz.U. Nr 114, poz. 946), który stanowił, iż dodawany ww. ustawą nowy ust. 3 art. 99 Konstytucji „ma zastosowanie do kadencji Sejmu i Senatu następujących po kadencji, w czasie której ustawa weszła w życie".

15 Odmiennie zob.: wyrok WSA w Opolu z 6.06.2019 r., II SA/Op 118/19, a także wyrok NSA z 27.07.2017 r., II OSK 2915/15, w którym Sąd, rozpatrując kwalifikowane wejście w życie nowelizacji z 2014 r. (dotyczącej gospodarki odpadowej), stwierdzil, że wobec ustanowienia 12-miesięcznego okresu przejściowego nie ma podstaw do uznania, że gmina nie może zmieniać w okresie przejściowym uchwał wydanych pod rządami dawnego prawa. 
ich rozpowszechnienia, a nawet może spowodować wypaczenie idei partycypacji. Przeciwko wprowadzeniu obligatoryjności przemawiają niepowodzenia budżetów partycypacyjnych $w$ innych krajach lub nawet wycofanie się $\mathrm{z}$ tego instrumentu w jego ojczyźnie (Brazylii) po niemal 30 latach jego stosowania. Z drugiej jednak strony istnieją kraje (np. Dominikana), w których budżet partycypacyjny ma charakter obligatoryjny na poziomie gmin, a także posiada odrębną regulację ustawową.

Obligatoryjność budżetu obywatelskiego w miastach na prawach powiatu w omawianej nowelizacji okazała się być najbardziej zaskakującym elementem. Eksperci budżetu obywatelskiego podkreślają bowiem, że „dla procesu budżetowania partycypacyjnego istotne znaczenie ma kondycja finansów publicznych (...). Dyspozycyjność zasobów finansowych jest kluczowa, bowiem trudno pogodzić cel i istotę budżetowania partycypacyjnego i jednocześnie konieczność uzasadnionych cięć w wydatkach publicznych. (...) Sytuacji takiej raczej nie przewidziano w nowych regulacjach prawnych w Polsce, wymuszając na miastach na prawach powiatu obowiązek posiadania $\mathrm{BP}^{\prime \prime 16}$. Jest to słuszna uwaga, uzasadniająca postulat przyszłej korekty przepisów ustawowych BO, która by ową obligatoryjność uzależniła np. od określonej wysokości zadłużenia danego miasta.

Zgodnie z art. 5a ust. 3 i 4 u.s.g., budżet obywatelski jest szczególną formą konsultacji społecznych, $\mathrm{w}$ ramach których mieszkańcy w bezpośrednim głosowaniu decydują corocznie o części wydatków budżetu gminy. Powyższe zaliczenie BO przez ustawodawcę do form konsultacji społecznych oznacza, że jego „obowiązkowe utworzenie" w miastach na prawach powiatu, o którym mowa w art. 5a ust. 5 u.s.g., należy rozumieć jako obowiązkowe konsultacje społeczne, które corocznie muszą być przeprowadzane przez organy miasta na prawach powiatu. W sytuacji więc, gdy w ramach zainicjowanej przez organy miasta na prawach powiatu procedury $\mathrm{BO}$ nie zostały zgłoszone żadne projekty albo projekty zgłoszone nie spełniały wymogów i nie mogły być poddane pod głosowanie lub w sytuacji zaistnienia innych nadzwyczajnych okoliczności, które miały negatywny wpływ na wynik konsultacji - zaplanowanie zadań BO w wydatkach budżetu tego miasta nie byłoby możliwe. Obowiązek ujęcia tych zadań w planie wydatków budżetu miasta na prawach powiatu ma więc charakter warunkowy, zaś jego spełnienie zależy ściśle od wyniku przeprowadzonych wcześniej obligatoryjnych konsultacji społecznych. Okoliczności te powinny być ustalane i brane pod uwagę zarówno przez skład orzekający regionalnej izby obrachunkowej (dalej: RIO), który opiniuje projekt

16 A. Sobol, A. Rzeńca, Ekspertyza dotyczaca budżetów obywatelskich w innych państwach, [w:] Informacja o wynikach kontroli. Funkcjonowanie budżetów partycypacyjnych (obywatelskich), Najwyższa Izba Kontroli. Delegatura w Gdańsku, Nr ewid. 20/2019/P/18/064/LGD, Gdańsk 2019, s. 97, https://www. nik.gov.pl/kontrole/P/18/064/ (dostęp: 15.10.2020). 
uchwały budżetowej, jak i kolegium RIO, które rozstrzyga o zgodności z prawem podjętej uchwały budżetowej. Okoliczności powyższe powinny być także wyjaśnione przez prezydenta miasta $\mathrm{w}$ raporcie o stanie gminy składanym radzie na podstawie art. 28aa u.s.g.

\section{Uchwała rady/sejmiku w sprawie budżetu obywatelskiego}

Dotychczasowa praktyka w zakresie tworzenia budżetów obywatelskich przez polskie samorządy wzbudzała wiele wątpliwości wśród mieszkańców, stąd w piśmiennictwie pojawiały się postulaty uregulowania tej instytucji w przepisach rangi ustawowej. W szczególności wskazywano na potrzebę uregulowania praw uczestników procedury, obowiązków organów gminy, gwarancji jawności i rzetelności tworzenia budżetów partycypacyjnych ${ }^{17}$. W poprzednim stanie prawnym istniały przypadki, że decyzję w sprawie utworzenia BO podejmował organ wykonawczy j.s.t., przeprowadzając konsultacje oraz procedurę wyboru projektów na podstawie własnego zarządzenia (uchwały), nawet nie zgłaszając tego aktu do publikacji w dzienniku urzędowym województwa, przyjmując, że nie jest on aktem prawa miejscowego $^{18}$. Obecnie to organ stanowiący j.s.t. decyduje o utworzeniu BO w momencie podejmowania uchwały w sprawie wymagań, jakie powinien spełniać projekt budżetu obywatelskiego (dalej: uchwała w sprawie $\mathrm{BO}$ ) na podstawie delegacji z art. 5a ust. 7 u.s.g., art. 3 d ust. 6 u.s.p., art. 10a ust. 6 u.s.w., przy czym, jak już wspomniano, $\mathrm{w}$ miastach na prawach powiatu uchwała ta ma charakter obligatoryjny.

Uchwały w sprawie BO, w związku z uznaniem tego instrumentu za formę przeprowadzania konsultacji, podlegają nadzorowi sprawowanemu przez wojewodę. Biorąc pod uwagę charakter norm konsultacyjnych, wskazanie na ten właśnie organ nadzoru w zakresie ww. uchwał wydaje się być w pełni uzasadnione, stąd też w większości województw to wojewodowie rozstrzygają o ich ważności lub nieważności. Jedynie w województwie mazowieckim nadzór nad tymi uchwałami sprawuje Kolegium RIO w Warszawie ${ }^{19}$. W rozstrzygnięciach nadzorczych podjętych w 2019 r. wobec uchwał w sprawie BO wskazywane były liczne naruszenia

17 D. Sześciło, Uwarunkowania prawne budżetu partycypacyjnego w Polsce, „Finanse Komunalne” 2012, 12 , s. 23.

18 Zob. odmiennie: wyrok WSA we Wrocławiu z 29.04.2011 r., III SA/Wr 20/11; wyrok WSA w Gliwicach z 14.01.2014 r., ISA/G1 1291/13; wyrok WSA w Gliwicach z 8.03.2016 r., IV SA/G1 1129/15. Por. R. Marchaj, Charakter prawny uchwaty rady gminy w sprawie budżetu obywatelskiego, "Samorząd Terytorialny" 2017, 11, s. 12-14.

19 Zob. np. uchwałę Nr 5.77.2019 Kolegium RIO w Warszawie z 19.02.2019 r. (Dz.Urz.Woj.Maz. z 2019 r., poz. 5983). 
prawa dotyczące np.: sposobu określenia wymaganej liczby podpisów mieszkańców popierających projekt ${ }^{20}$, zapewnienia równości i bezpośredniości głosowania nad projektami ${ }^{21}$, podawania niepotrzebnych danych osobowych przez mieszkańca głosującego na projekt ${ }^{22}$, trybu odwołania od decyzji o niedopuszczeniu projektu do głosowania ${ }^{23}$.

Uchwały w sprawie BO niejednokrotnie zawierają także postanowienia powiązane z procedurą uchwalania budżetu gminy. Przykładowo postanawiają, iż opublikowanie listy zadań przyjętych do realizacji nastąpi po przyjęciu budżetu miasta na kolejny rok budżetowy ${ }^{24}$, a więc z pominięciem ustawowego wymogu ujmowania tej listy w uchwale budżetowej.

\section{Planowanie zadań budżetu obywatelskiego w uchwale budżetowej j.s.t.}

Zarówno w przypadku obligatoryjnego BO w miastach na prawach powiatu, jak i w przypadku fakultatywnego $\mathrm{BO} w$ pozostałych gminach oraz powiatach i województwach, ustawodawca po raz pierwszy zdefiniował ten budżet, a także zwiększył rangę prawną zadań wybieranych w jego ramach. W nowej regulacji art. 5a ust. 4 u.s.g. stwierdza bowiem: „W ramach budżetu obywatelskiego mieszkańcy w bezpośrednim głosowaniu decydują corocznie o części wydatków budżetu gminy. Zadania wybrane w ramach budżetu obywatelskiego zostają uwzględnione w uchwale budżetowej gminy. Rada gminy w toku prac nad projektem uchwały budżetowej nie może usuwać lub zmieniać w stopniu istotnym zadań wybranych w ramach budżetu obywatelskiego" (adekwatny przepis zawierają art. $3 d$ ust. 4 u.s.p., art. 10a ust. 4 u.s.w.). Pomimo dość ogólnego brzmienia powyższej regulacji należy ją uznać za przełomową w kwestii umiejscowienia BO w procedurze budżetowej.

20 Rozstrzygnięcie Nadzorcze Nr NP.II.4131.1.279.2019 Wojewody Śląskiego z 30.03.2019 r. (Dz.Urz. Woj.Śląsk. z 2019 r., poz. 3526), wyrok WSA w Gliwicach z 21.01.2020 r., III SA/G1 944/19.

21 Rozstrzygnięcie Nadzorcze Nr NPII.4131.1.303.2019 Wojewody Śląskiego z 17.05.2019 r. (Dz.Urz. Woj.Śląsk. z 2019 r., poz. 3825), postanowienie WSA w Gliwicach z 15.01.2020 r., III SA/G1 938/19.

22 Rozstrzygnięcie Nadzorcze Nr NPII.4131.1.570.2019 Wojewody Śląskiego z 9.08.2019 r. (Dz.Urz. Woj.Śląsk. z 2019 r., poz. 5577).

23 Uchwała Nr 5.77.2019 Kolegium RIO w Warszawie z 19.02.2019 r. (Dz.Urz.Woj.Maz. z 2019 r., poz. 5983). Por.: wyrok WSA w Olszynie z 7.05.2019 r., II SAB/Ol 14/19, w którym Sąd odrzucił skargę mieszkańca na bezczynność organu administracji (Prezydenta Miasta) w zakresie odpowiedzi na pismo kwestionujące wybór projektu BO - budowy drogi, która „nie służy mieszkańcom osiedla, lecz stanowi dojazd wyłącznie do prywatnych działek".

24 Zob. uchwałę Nr XIV/161/2019 Rady Miejskiej w Czeladzi z 16.09.2019 r. w sprawie utworzenia Budżetu Obywatelskiego w Mieście Czeladź (Dz.Urz.Woj.Śląsk. z 2019 r., poz. 6341). 
Regulacja ta przyznaje szczególną rolę radzie/sejmikowi w uchwalaniu zadań BO oraz wydatków na te zadania, która powinna być już bezwzględnie przestrzegana przy uchwalaniu budżetów j.s.t. na 2020 rok i lata następne. Jednakże wobec ogólnego charakteru powyższej regulacji przy analizie uchwały budżetowej j.s.t. na 2020 rok (a także na lata następne) organy nadzoru muszą rozstrzygnąć następujące dwa dylematy:

1) Jaki sposób „uwzględnienia w uchwale budżetowej” zadań wybranych w ramach BO może być uznany za dopuszczalny prawnie? Skoro ustawodawca zastosował zwrot "uwzględnione w uchwale budżetowej" (a nie np. tylko "uwzględnione w wydatkach budżetu miasta"), oznacza to, iż wydatki i zadania wybrane $w$ ramach $\mathrm{BO}$ powinny być wyodrębnione $\mathrm{w}$ formie załącznika do uchwały budżetowej (z podaną kwotą, nazwą zadania i podziałką klasyfikacji budżetowej wydatku) ${ }^{25}$. Obok tak sporządzonego załącznika (zestawienia) rada może przewidzieć określoną kwotę na rezerwę celową na dofinansowanie zadań realizowanych w ramach BO, która jednak, począwszy od 2020 r., będzie dopuszczalna wyłącznie pod warunkiem zastosowania się przez radę $\mathrm{w}$ pierwszej kolejności do powyższego wymogu uwzględnienia w uchwale budżetowej zadań wybranych w ramach BO. Sama rezerwa celowa na zadania realizowane w ramach $\mathrm{BO}$ (która dość często była tworzona w budżetach gmin) nie może być już bowiem uznana za spełnienie wymogu "uwzględnienia" tych zadań w uchwale budżetowej;

2) Jak ocenić „istotny stopień” zmian zadań wybranych w ramach BO dokonanych przez radę $\mathrm{w}$ toku prac nad projektem uchwały budżetowej, jeśli do takich zmian dojdzie? Zgodnie z nową zasadą, rada może wprowadzać określone zmiany w zadaniach BO pod warunkiem, że zmiany te nie będą miały charakteru istotnego. Jak wskazuje się w literaturze, zmiany dokonywane w projekcie uchwały budżetowej przez radę/sejmik „,nie mogą prowadzić do tego, że niemożliwe okaże się zrealizowanie celu przewidzianego w wynikach budżetu obywatelskiego w skali, która z nich wynika"26.

Należy podkreślić, iż przytoczona wyżej regulacja wyraźnie wskazuje, iż owo uwzględnianie zadań BO w uchwale budżetowej powinno mieć miejsce w procesie prac rady nad projektem uchwały budżetowej. Potwierdza to zdanie zawarte

25 O roli załączników do uchwały budżetowej j.s.t. (na przykładzie tzw. załącznika dotacyjnego) zob. szerzej: A. Ostrowska, Samorząowe prawo dotacyjne. Dotacje jako wydatki jednostek samorzadu terytorialnego, Warszawa 2018, s. 247-249.

26 S. Gajewski, Ustawy samorządowe. Nowe instytucje. Analiza z przykładami i wzorami dokumentów, Warszawa 2018, s. 24. 
W ww. przepisie twierdzące, iż „rada gminy w toku prac nad projektem uchwały budżetowej nie może usuwać lub zmieniać w stopniu istotnym zadań wybranych w ramach budżetu obywatelskiego". Oznacza to, że do dnia sesji budżetowej cała procedura wybierania zadań w ramach BO (łącznie z etapem odwoławczym) powinna być zakończona, co w przypadku budżetów na 2020 rok i lata następne nie powinno już wywoływać problemów czasowych.

\section{Ustawowy limit wysokości budżetu obywatelskiego w miastach na prawach powiatu}

Poza wyżej wymienionymi dylematami dodatkowym zadaniem stojącym przed organem nadzoru jest badanie poprawności wysokości BO w miastach na prawach powiatu, który zgodnie z art. 5 a ust. 5 u.s.g., ma wynosić co najmniej $0,5 \%$ wydatków gminy zawartych w ostatnim przedłożonym sprawozdaniu z wykonania budżetu. Badanie przestrzegania wyżej wymienionego limitu stanie się problematyczne w sytuacji, gdy łączna kwota BO wykazana w uchwale budżetowej miasta na prawach powiatu okaże się być niższa od powyższego limitu. Wówczas w uzasadnieniu do projektu uchwały budżetowej powinno znaleźć się wyjaśnienie tej okoliczności z podaniem przyczyny mniejszej wysokości BO od tej wymaganej przez ustawę (np. z powodu wpłynięcia mniejszej liczby projektów lub odrzucenia dużej liczby projektów niespełniających wymogów). Organ nadzoru powinien takiego wyjaśnienia wymagać na etapie badania projektu uchwały budżetowej oraz, bez wątpienia, o okoliczności tej właściwy skład orzekający powinien wspomnieć w opinii w sprawie projektu uchwały budżetowej wydawanej na podstawie art. 13 pkt 3 ustawy o RIO ${ }^{27}$. Należy stwierdzić, że ustawowy limit wysokości BO jest bezwzględnie obowiązujący na etapie ogłaszania naboru projektów w ramach BO i wydzielaniu puli środków budżetowych na ten cel. Natomiast na etapie podejmowania uchwały budżetowej limit ten staje się względnie obowiązujący, gdyż jego ostateczne spełnienie jest zależne od aktywności jego mieszkańców.

Uwzględniając powyższe, nie można uznać za słuszne stanowisko organu nadzoru kwestionujące postanowienie uchwały w sprawie BO ustanawiające obowiązek organu wykonawczego podawania planowanej wysokości środków BO na stronie biuletynu informacji publicznej gminy. Zdaniem Kolegium RIO w Warszawie „do kompetencji rady należy wskazanie wartości wydatków wyrażonej w \%, jaką gmina będzie corocznie przeznaczać na budżet obywatelski. (...) kompetencja

27 Ustawa z 7.10.1992 r. o regionalnych izbach obrachunkowych (Dz.U. z 2016 r., poz. 561 z późn. zm.). 
ta nie może być scedowana na organ wykonawczy"28. Ze stanowiskiem tym trudno się zgodzić, gdyż przepisy delegacyjne art. $5 a$ ust. 7 u.s.g., art. $3 d$ ust. 6 u.s.p., art. 10a ust. 6 u.s.w. nie formułują powyższej kompetencji rady.

\section{Dokonywanie wydatków na zadania wybrane w ramach budżetu obywatelskiego}

Na charakter wydatków budżetowych dokonywanych w ramach budżetu obywatelskiego wskazują nowe zasady określone w art. 5 a ust. 4 u.s.g., art. $3 d$ ust. 4 u.s.p., art. 10a ust. 4 u.s.w. Jedna $\mathrm{z}$ nich stanowi, iż zadania wybrane $\mathrm{w}$ ramach budżetu obywatelskiego są uwzględniane w uchwale budżetowej. Ustawodawca zwiększył rolę rady/sejmiku w procedurze uchwalania zadań wybranych w ramach BO i wydatków na nie przeznaczanych prawdopodobnie z powodu wspomnianej wcześniej kontrowersyjności niektórych z nich, a także wzrostu wysokości tych wydatków ${ }^{29}$. To właśnie organ stanowiący j.s.t. jest więc obecnie ostateczną „instancją" akceptującą zadania BO, która w trakcie sesji budżetowej powinna posiadać ich wykaz wraz z kwotami wydatków. Następnie organ ten musi uchwalić powyższy wykaz bez dokonywania w nim zmian lub może w nim dokonać pewnych zmian niemających istotnego charakteru. Niekonsekwencję ustawodawcy w zakresie zwiększenia roli organu stanowiącego $\mathrm{w}$ procedurze uchwalania zadań wybranych $\mathrm{w}$ ramach BO można jednak wskazać w odniesieniu do wprowadzonego zakazu usuwania tych zadań. Kłóci się to z funkcją kontrolną tego organu oraz jego kompetencją do dokonywania zmian w projekcie uchwały budżetowej określoną w art. 240 ust. 2 u.f.p. Zakaz ten $\mathrm{z}$ drugiej strony podkreśla wagę procedury wyłaniania zdań BO oraz jest przejawem „uszanowania" głosu obywateli w procesie wyboru celu przeznaczenia części wydatków publicznych ${ }^{30}$.

Należy przyznać, iż w przeciwieństwie do poprzednio obowiązującego stanu prawnego, kiedy to pełnię władztwa wydatkowego w zakresie budżetu obywatelskiego posiadał organ wykonawczy j.s.t., w obecnie obowiązującym stanie prawnym organ ten tę pełnię władztwa niejako utracił i jest zobowiązany w tym zakresie współpracować z organem stanowiącym, uznając jego uprawnienia w za-

28 Uchwała Nr 19.263.2019 Kolegium RIO w Warszawie z 3.09.2019 r. (Dz.Urz.Woj.Maz. z 2019 r., poz. 12781).

29 Wartość środków przeznaczanych na BO w 2018 r. wynosiła np.: w Warszawie $61 \mathrm{mln}$ zl, w Łodzi $40 \mathrm{mln}$ zł, we Wrocławiu $25 \mathrm{mln}$ zł, http://urbnews.pl/budzety-obywatelskie-2018/ (dostęp: 12.06.2020).

30 Por.: D. Rybińska, Instytucja budżetu obywatelskiego jako narzędzia rozwoju samorządu lokalnego, „Finanse i Prawo Finansowe" 2018, 17, s. 52. 
kresie uchwalania wydatków na zadania BO oraz dokonywania zmian w tych wydatkach. Urzeczywistnienie zwiększonej roli rady/sejmiku w obecnej procedurze uchwalania zadań BO wymaga jednak odpowiedniej (idącej w tym kierunku) interpretacji przepisów w zakresie następujących zagadnień:

1) tworzenia $w$ budżecie j.s.t. rezerwy celowej na zadania wybrane $w$ ramach BO - Utworzenie rezerwy celowej na zadania realizowane w ramach BO, w świetle nowych przepisów ustawowych, nie może być uznane za spełnienie wymogu „uwzględnienia” tych zadań w uchwale budżetowej. Dopuszczenie uchwalenia rezerwy celowej na zadania wybrane w ramach BO należałoby uznać za interpretację contra legem, zakładającą, że nowe przepisy ustawowe nie przyniosły żadnych zmian w tym zakresie. Ustalona w budżecie j.s.t. rezerwa celowa na zadania wybrane $\mathrm{w}$ ramach $\mathrm{BO}$ bez uwzględniania wykazu tych zadań i wydatków planowanych na ich realizację w uchwale budżetowej powinna być unieważniona przez organ nadzoru z powodu istotnego naruszenia art. 5a ust. 4 u.s.g. w zw. z art. 22 ust. 2 pkt 1 u.f.p. ${ }^{31}$;

2) zmniejszania lub zwiększania wydatków na zadania $\mathrm{BO} w$ trakcie roku budżetowego - Zmiana kwoty wydatku na zadanie wybrane w ramach BO jest częstą koniecznością występującą w praktyce samorządowej. Może ona wywołać sprzeciw projektodawców lub mieszkańców głosujących na dany projekt, jednakże w świetle przepisów u.s.g. i u.f.p. należy ją uznać za dopuszczalną. Przepisy te bowiem nie regulują kwestii charakteru oraz dokonywania wydatków na realizację zadań BO. Upoważnienie ustawowe dla uchwały w sprawie BO (art. 5 a ust. 7 u.s.g., art. 3 d ust. 6 u.s.p., art. 10a ust. 6 u.s.w.) nie formułuje nawet delegacji do uregulowania powyższej kwestii przez organ stanowiący. Organy nadzoru (wojewodowie) oraz sądy administracyjne wskazują, że „kwestie dotyczące niewykorzystanych środków finansowych na zrealizowanym projekcie, modyfikacji projektu w trakcie jego realizacji, czy też nierozdysponowanych środków nie dotyczą wymagań, jakie powinien spełniać projekt budżetu obywatelskiego (...), a więc nie posiadają umocowania w delegacji ustawowej"32. Wobec braku uregulowa-

31 Z całą pewnością także nie jest już możliwe dokonywanie wydatków na zadania BO w ramach rezerwy ogólnej budżetu j.s.t., co do której swoboda dysponowania (połączona z samodzielnością wyznaczania celów przeznaczenia wydatku) organu wykonawczego jest jeszcze większa niż w przypadku rezerwy celowej. W doktrynie dopuszcza się jednak kreowanie nowych wydatków (zadań) inwestycyjnych przez organ wykonawczy j.s.t. w ramach rezerw budżetowych. Zob. M. Tyniewicki, Funkcjonowanie rezerw w budżecie jednostki samorządu terytorialnego - wybrane problemy praktyczne, „Przegląd Podatków Lokalnych i Finansów Samorządowych” 2014, 8, s. 29-35.

32 Postanowienie WSA w Gliwicach z 15.01.2020 r., III SA/Gl 938/19. Jakkolwiek w niektórych uchwałach w sprawie BO występują przepisy regulujące zasady „przesuwania” środków między zadaniami BO, a nawet wyodrębniania w ogólnej puli środków BO tzw. rezerwy, którą dysponuje 
nia ustawowego możliwości dokonywania zmian kwot wydatków na zadania wybrane $\mathrm{w}$ ramach $\mathrm{BO} \mathrm{w}$ trakcie roku budżetowego ${ }^{33}$ należy przyjąć, iż wydatki te podlegają takim samym zasadom, jakie obowiązują przy dokonywaniu pozostałych wydatków budżetowych j.s.t. Organ wykonawczy, realizując zadania wybrane $\mathrm{w}$ ramach $\mathrm{BO}$, powinien więc przestrzegać zasad gospodarki finansowej określonych w art. 254 u.f.p., natomiast $\mathrm{w}$ zakresie dokonywania zmian kwot wydatków na te zadania powinien działać na podstawie norm art. 257 u.f.p. oraz w ramach upoważnień udzielonych mu przez organ stanowiący na podstawie art. 258 u.f.p. Zmiana kwoty wydatku lub nawet rezygnacja z realizacji projektu $\mathrm{BO} w$ trakcie roku budżetowego przez organ wykonawczy j.s.t. jest dopuszczalna prawnie, gdyż to właśnie ten organ wykonuje budżet i w tym zakresie jest ograniczony jedynie zasadami u.f.p. i upoważnieniami udzielonymi mu przez organ stanowiący na podstawie art. 258 u.f.p. Okoliczności powyższe mogą być jedynie negatywnie ocenione przez radnych przy udzielaniu organowi wykonawczemu wotum zaufania, gdyż zgodnie z art. 28aa ust. 2 u.s.g. raport o stanie gminy obejmuje m.in. podsumowanie realizacji budżetu obywatelskiego. Potrzeba dokonania zmian w wydatkach na BO (lub nawet rezygnacji z części z nich) ujawnia się w okresie epidemii COVID-19, kiedy to niektóre projekty o charakterze społecznym okazują się być niemożliwe do zrealizowania. Organ wykonawczy j.s.t. posiada nawet odrębne upoważnienie w ustawie "covidowej” do dokonania zmian w planie dochodów i wydatków budżetu j.a.t., w tym dokonania przeniesień wydatków między działami klasyfikacji budżetowej34;

3) uchwalania zadań BO o charakterze wieloletnim - Dopuszczanie możliwości uchwalania zadań $\mathrm{BO}$ o charakterze wieloletnim co do zasady byłoby sprzeczne z rocznym charakterem tego budżetu, który jest wyrażony wprost

tzw. Rada Budżetu Obywatelskiego. Zob. § 29 Załącznika Nr 1 do uchwały Nr 216/XX/20 Rady Miejskiej w Łomży z 22.01.2020 r. w sprawie Regulaminu Budżetu Obywatelskiego Miasta Łomża (Dz.Urz.Woj.Podl., poz. 649), dalej: uchwała Nr 216/XX/20 Rady Miejskiej w Łomży.

33 Konieczność wypełnienia powyższej luki prawnej nie została jednak wymieniona wśród postulatów de lege ferenda sformułowanych przez NIK w: Informacji o wynikach kontroli. Funkcjonowanie budżetów partycypacyjnych (obywatelskich), Nr ewid. 20/2019/P/18/064/LGD, Najwyższa Izba Kontroli, Delegatura w Gdańsku, Gdańsk 2019, s. 70-98, https://www.nik.gov.pl/aktualnosci/budzety-partycypacyjne.html (dostęp: 15.10.2020). Jakkolwiek w ww. Informacji NIK wskazuje na trudności związane z realizacją projektów BO tj.: brak ofert w ogłaszanych przetargach, wyższe wartości ofert wykonawców od środków finansowych określonych we wnioskach, zmiany cen rynkowych pomiędzy rokiem szacowania kosztów, a rokiem realizacji zadania.

34 Art. 15zn pkt 1 ustawy z 2.03.2020 r. o szczególnych rozwiązaniach związanych z zapobieganiem, przeciwdziałaniem i zwalczaniem COVID-19, innych chorób zakaźnych oraz wywołanych nimi sytuacji kryzysowych (Dz.U. poz. 374 z późn. zm.). 
$\mathrm{w}$ art. 5a ust. 4 u.s.g., stanowiącym, iż „w ramach budżetu obywatelskiego mieszkańcy w bezpośrednim głosowaniu decydują corocznie o części wydatków budżetu gminy". Czy jednak z powyższej normy wynika zasada rocznego charakteru samych wydatków przeznaczanych na zadania BO czy też tylko zasada corocznego przeprowadzania głosowania mieszkańców w sprawie przeznaczenia części wydatków na określone zadania? Nie można z powyższej normy (będącej definicją budżetu obywatelskiego) wywodzić bezwzględnego zakazu planowania i dokonywania wydatków na wieloletnie zadania (projekty) budżetu obywatelskiego. W tym przypadku jednak podstawa do przyjmowania takiego wieloletniego zadania oraz poddawania go pod głosowanie powinna znajdować się w uchwale w sprawie $\mathrm{BO}$, gdyż okres realizacji zadania BO mieści się w kategorii „wymagań, jakie powinien spełniać projekt budżetu obywatelskiego", które są określane w tej uchwale. Przykładowo Regulamin Budżetu Obywatelskiego w Katowicach przewiduje, że: „,w wyjątkowych przypadkach właściwa komórka organizacyjna Urzędu Miasta Katowice lub jednostka organizacyjna miasta Katowice oceniająca projekt zadania dotyczący inwestycji infrastrukturalnych, może określić czas jego realizacji na okres nieprzekraczający dwóch lat" ${ }^{\prime \prime 3}$. Podobnie, Regulamin Budżetu Obywatelskiego Miasta Łomża zawiera regulację stanowiącą, że „W przypadku obiektywnych trudności w realizacji zadania $\mathrm{w}$ danym roku, zadanie zostanie uwzględnione $\mathrm{w}$ budżecie Miasta Łomża na rok kolejny"36. Powyższe regulacje uchwał w sprawie BO wprawdzie są przykładem słusznego rozwiązania racjonalizującego praktykę w zakresie realizacji projektów BO, jednakże wymagają zastosowania odpowiednich przepisów prawa budżetowego. Prawo to zaś w zakresie dokonywania wydatków przekraczających rok budżetowy przewiduje wyłącznie dwie konstrukcje prawne: konstrukcję tzw. przedsięwzięcia wieloletniego ujmowanego w załączniku do uchwały w sprawie wieloletniej prognozy finansowej j.s.t. (art. 226-232 u.f.p.) oraz konstrukcję wydatków niewygasających (art. 263 ust. 2-7 u.f.p.). W zależności więc od momentu zaistnienia konieczności realizowania wieloletniego zadania BO należy zastosować odpowiednią konstrukcję wydatków wieloletnich zgodnie z przepisami ustawy o finansach publicznych;

\footnotetext{
$35 \S 3$ ust. 7 pkt 8 Załącznika Nr 1 do uchwały Nr V/80/19 Rady Miasta Katowice z dnia 7 marca 2019 r. w sprawie określenia zasad i trybu Budżetu Obywatelskiego w Katowicach (Dz.Urz.Woj.Śląsk. z 2019 r., poz. 2065).

36 § 3 Załącznika Nr 1 do uchwały Nr 216/XX/20 Rady Miejskiej w Łomży.
} 
4) dokonywania wydatków budżetowych na zadania wybrane w ramach BO przewidziane do realizacji „na cudzym gruncie” - Dokonywanie wydatków na zadania wybrane $w$ ramach $B O$ przewidziane do realizacji „na cudzym gruncie” jest niezwykle ryzykowne dla organów j.s.t. biorąc pod uwagę zasadę superficies solo cedit uregulowaną w art. 48 i art. 191 k.c. ${ }^{37}$. Należy więc pozytywnie ocenić samorządy, które w uchwałach w sprawie BO wprost postanawiają, iż „zgłaszane zadania muszą być zlokalizowane wyłącznie na terenach będących własnością miasta" ${ }^{38}$. Uchwały w sprawie BO innych miast (Warszawa, Gliwice) przywidują jednak możliwość realizacji zadania $w$ ramach $\mathrm{BO}$ na terenach pozostających we władaniu samorządu, przy czym, jak wskazuje RIO w Gdańsku, w tym przypadku „gmina powinna uzyskać tytuł prawny do majątku obcego (dzierżawę, użyczenie), a dodatkowo w umowie $\mathrm{z}$ dysponentem tego majątku winno ustalić się zasady wzajemnych rozliczeń nakładów czynionych przez gminę"39. Uchwała Rady Miasta Katowice w sprawie BO przewidywała możliwość zgłaszania zadań BO realizowanych na terenie spółdzielni mieszkaniowej lub Katowickiego Towarzystwa Budownictwa Społecznego, jednakże w wyniku nowelizacji tej uchwały przeprowadzonej w 13.02.2020 r. ${ }^{40}$ możliwość tę wykreślono, pozostawiając jedynie zasadę, iż zadanie zgłoszone do BO powinno być zlokalizowane na terenie stanowiącym własność miasta Katowice lub Skarbu Państwa będącym w użytkowaniu wieczystym miasta Katowice.

\section{Podsumowanie}

Uchwalenie ustawowych podstaw budżetu obywatelskiego w Polsce z jednej strony niejako zalegalizowało stosowaną dotychczas praktykę samorządową, lecz z drugiej strony jednoczesne wprowadzenie obligatoryjności tego budżetu w miastach na prawach powiatu zniekształciło ideę partycypacji. Obligatoryjność tą należy uznać za rozwiązanie niegospodarne w przypadku miast na prawach powiatu posiadających trudną sytuację finansową (np. realizujących program naprawczy).

37 Ustawa z 23.04.1964 r. - Kodeks cywilny (tj.: Dz.U. z 2019 r., poz. 1145).

38 Zob. np.: pkt 12 Załącznika do uchwały Nr 216/XX/20 Rady Miejskiej w Łomży.

39 Problematyka finansowania przez gminę w ramach budżetu obywatelskiego zadań realizowanych na terenach stanowiących własność spótdzielni mieszkaniowych bądź wspólnot mieszkaniowych, Wyjaśnienia Nr RP.0441/110/10/1/2019 z 5.03.2020 r., Regionalna Izba Obrachunkowa w Gdańsku, http://bip. gdansk.rio.gov.pl/?a=4926 (dostęp: 15.10.2020).

40 Uchwała Nr XVI/396/20 Rady Miasta Katowice z 13.02.2020 r. zmieniająca uchwałę w sprawie określenia zasad i trybu Budżetu Obywatelskiego w Katowicach (Dz.Urz.Woj.Śląsk., poz. 1538). 
Opisana w artykule geneza wprowadzania budżetów partycypacyjnych w innych krajach, która wskazywała na traktowanie go niejednokrotnie jako narzędzia marketingu politycznego, nie może jednak stanowić argumentu przemawiającego za likwidacją tego instrumentu. Budżet obywatelski bowiem posiada znacznie więcej zalet niż wad oraz faktycznie jest on (obok funduszu sołeckiego) najskuteczniejszą formą partycypacji społecznej. Należy pozytywnie ocenić wprowadzone z dniem 31.01.2018 r. ustawowe podstawy stosowania tego instrumentu przez polskie samorządy, w tym ustawową delegację dla miejscowych aktów prawa miejscowego podejmowanych przez organy stanowiące j.s.t. w tym zakresie. Słusznie ustawodawca zwiększył rolę rady/sejmiku w procedurze BO, jednakże rola ta nadal jednak pozostaje niejednoznaczna m.in. w zakresie zmian, które rada/sejmik może dokonywać w zadaniach BO w trakcie prac nad projektem uchwały budżetowej, a także dokonywania tych zmian w ciągu roku budżetowego. Nawet wprowadzony przez ustawodawcę nakaz uwzględniania w uchwale budżetowej zadań wybranych w ramach budżetu obywatelskiego jest w praktyce samorządowej różnorodnie przestrzegany $^{41}$, jakkolwiek można wskazać samorządy, które powyższy nakaz zrealizowały wzorcowo ${ }^{42}$. Istotne wątpliwości wzbudza również realizowanie zadań BO na prywatnej nieruchomości. Ze względu na zagrożenia związane z zasadą superficies solo cedit jednostki samorządu terytorialnego, jako jednostki sektora finansów publicznych dokonujące wydatków ze środków publicznych powinny ze szczególną rozwagą rozpatrywać projekty budżetu obywatelskiego realizowane na cudzym gruncie.

\section{Bibliografia}

Czarnecki K., Udział mieszkańców w ustalaniu wydatków budżetu gminy w ramach tzw. budżetu partycypacyjnego (na przyktadzie Torunia w latach 2013-2014), „Prawo Budżetowe Państwa i Samorządu" 2014, 2.

Ewaluacja procesu wdrażania budżetu obywatelskiego w Krakowie w 2016 r. Raport końcowy, Miejskie Centrum Dialogu, Kraków 2016, https://www.bip.krakow.pl/?dok_id=73898 (dostęp: 15.10.2020).

Gajewski S., Ustawy samorzadowe. Nowe instytucje. Analiza z przykładami i wzorami dokumentów, Warszawa 2018.

41 Zob. uchwałę Nr VI/16/3/2019 Sejmiku Województwa Śląskiego z 16.12.2019 r. w sprawie budżetu Województwa Śląskiego na 2020 rok (Dz.Urz.Woj.Śląsk., poz. 9052), w której zaplanowano jedynie rezerwę celową na sfinansowanie zadań, które zostaną wybrane w grudniu w ramach I edycji Marszałkowskiego Budżetu Obywatelskiego w wysokości $10 \mathrm{mln}$ zł.

42 Zob. Załącznik nr 5 do uchwały Nr XIV/286/19 Rady Miasta Tychy z 12.12.2019 r. w sprawie budżetu miasta Tychy na 2020 rok (Dz.Urz.Woj.Śląsk., poz. 9014). 
Informacja o wynikach kontroli. Funkcjonowanie budżetów partycypacyjnych (obywatelskich), Nr ewid. 20/2019/P/18/064/LGD, Najwyższa Izba Kontroli, Delegatura w Gdańsku, Gdańsk 2019, https://www.nik.gov.pl/aktualnosci/budzety-partycypacyjne.html (dostęp: 15.10.2020).

Kościuk D.J., Kulikowska-Kulesza J.E., Zawadzka-Pąk U.K., Lotko E., Budżet partycypacyjny jako instrument wspierania realizacji lokalnych zadań publicznych - analiza administracyjno-finansowa miast wojewódzkich, [w:] B. Dolnicki (red.), Sposoby realizacji zadań publicznych, Warszawa 2017.

Kowanda C., Bierzcie i dzielcie, „Polityka” 2014, 14.

Marchaj R., Charakter prawny uchwaty rady gminy w sprawie budżetu obywatelskiego, „Samorząd Terytorialny" 2017, 11.

Ostrowska A., Samorzadowe prawo dotacyjne. Dotacje jako wydatki jednostek samorzadu terytorialnego, Warszawa 2018.

Problematyka finansowania przez gminę w ramach budżetu obywatelskiego zadań realizowanych na terenach stanowiących własność spótdzielni mieszkaniowych bądź wspólnot mieszkaniowych, Regionalna Izba Obrachunkowa w Gdańsku, Wyjaśnienia Nr RP.0441/110/10/1/2019 z 5.04.2019 r., http://bip.gdansk.rio.gov.pl/?a=4926 (dostęp: 15.10.2020).

Rajca L., Local governance a partycypacja obywateli, [w:] J. Wojnicki (red.), Europejskie modele samorzadu terytorialnego. Stan obecny i perspektywy, Warszawa 2014.

Rajca L., Reformy samorządu terytorialnego w Anglii w latach 1997-2010, Torun 2012.

Rybińska D., Instytucja budżetu obywatelskiego jako narzędzia rozwoju samorządu lokalnego, „Finanse i Prawo Finansowe” 2018, 17.

Sobol A., Rzeńca A., Ekspertyza dotyczaca budżetów obywatelskich w innych państwach, [w:] Informacja o wynikach kontroli. Funkcjonowanie budżetów partycypacyjnych (obywatelskich), Najwyższa Izba Kontroli. Delegatura w Gdańsku, Nr ewid. 20/2019/P/18/064/LGD, https://www.nik.gov.pl/aktualnosci/budzety-partycypacyjne.html (dostęp: 15.10.2020).

Stoker G., Transforming Local Governance: from Thatcherism to New Labour, London 2004. Sześciło D., Uwarunkowania prawne budżetu partycypacyjnego w Polsce, „Finanse Komunalne" 2012, 12.

Tyniewicki M., Funkcjonowanie rezerw w budżecie jednostki samorządu terytorialnego - wybrane problemy praktyczne, „Przegląd Podatków Lokalnych i Finansów Samorządowych” 2014, 8.

Zawadzka-Pąk U. K., Ochrona dobra wspólnego poprzez budżet partycypacyjny (obywatelski). Studium aksjologiczno-prawne, Białystok 2019. 